\title{
Residential mobility in context: \\ Interpreting behavior in the housing market*
}

\author{
William A. V. Clark \\ University of California. Department of Geography and California Center \\ for Population Research \\ wclark@geog.ucla.edu
}

\begin{abstract}
Residential mobility is the process whereby individuals and households adjust their locations in cities. These moves, in the aggregate, change neighborhoods as well as providing specific housing outcomes for households and families as a result of the move. The literature on residential change has evolved from cross-sectional studies of family structure and their housing circumstances, to life course analyses of the motivations for moving, the contexts in which the moves occur, and the intersection of life course change and housing choice. The combined work of demographers, geographers, economists and sociologists has provided a much clearer and more nuanced understanding of behavior in the housing market than was possible with cross-sectional analyses. This paper reviews the evolution of life course approaches to residential mobility and discusses the current state of the research literature.
\end{abstract}

Keywords: mobility; life course; housing markets; neighborhoods; residential sorting

* Some of the material in this paper was originally prepared for a seminar on housing hosted by Professor Fiona Steele (The Housing Symposium, Royal Society, London, 2013), and further developed for the meeting Seminario Internacional Sobre Movilidad Residencial en Areas Metropolitanas at Granada, Andalusia, February, 2016. The presentation draws on material from those seminars and my previously published papers. I would like to thank Ricardo Duque Calvache and Isabel Palomores Linares for the invitation to participate in the Seminar in Granada, Andalusia, and Rory Coulter for comments on an earlier version of this paper. 
Resumen. La movilidad residencial en su contexto: interpretar el comportamiento en el mercado residencial

La movilidad residencial es el proceso por el cual los individuos y hogares ajustan su localización en la ciudad. Estos cambios, de manera agregada, transforman los barrios al tiempo que producen efectos específicos sobre los hogares y las familias. La literatura sobre cambios de residencia ha evolucionado desde los planteamientos transversales sobre la estructura familiar y las condiciones de su domicilio hacia análisis desde la perspectiva del curso vital de las razones para mudarse, los contextos en que ocurren los cambios, y la intersección de los cambios vitales y la elección residencial. El trabajo combinado de demógrafos, geógrafos, economistas y sociólogos ha proporcionado una comprensión más clara y matizada de lo que era posible con análisis transversales. Este artículo revisa la evolución de los acercamientos a la movilidad residencial desde el curso vital, y debate el estado de la cuestión en la literatura de investigación.

Palabras clave: movilidad; curso vital; mercados residenciales; barrios; clasificación residencial

\section{Summary}

1. Introduction 5. Neighborhoods and their role

2. Life cycle to life course

3. Moving and staying over the life course - attachment and duration

4. Sorting and selection: People in places
6. Institutions, policy and mobility

7. Observations and the future research agenda on residential mobility

Bibliographic references

\section{Introduction}

Residential mobility matters not just for families and individuals but for cities and society more broadly. The underlying premise of a mobile society is that enabling people to move enables them to improve their housing situation, their residential environment and their economic opportunities. Over a very long period, especially in European and United States contexts, a substantial amount of residential mobility was motivated by the desire to move from renting to owning or from smaller to larger houses and that dynamic is still important in the housing market. Longer distance moves, migration between cities and regions involved not just changing a house but often changing communities and jobs, and is motivated by a complex web of decisions related to the idea of improving both the economic and social context within which households live.

The research interest in why people move and their patterns of relocation behavior is also of broad interest to society. The moves affect our communities as some grow and others decline; they change neighborhood contexts as different ethnic groups succeed one another, and in the long run residential moves are the engine that directs growth and regional change. Understanding mobility then is of more than academic interest and has wide-ranging implications for 
planners, and those concerned with housing policies. At the micro level, at the level of individual behavior, it is also the process that matches buyers and sellers, those with houses and apartments to rent and those who want to buy or rent.

However, as others have observed, there has been a disjunction between the studies of residential choice and mobility and the study of housing markets (Myers, 1996). Economists who examined the operation of the housing market did not focus on how changing family composition affected mobility and choice, or how housing costs affected family formation. Demographers who examined fertility and fertility change did not always connect those changes to the housing market. Geographers studied mobility but did not always link the residential moves to the changing housing stock or neighborhood outcomes. Planners worried about design and functionality, but often assumed that their decisions were the ones which consumers wanted. Now there is real interest in the way in which housing markets, housing choices and mobility decisions and wider demographic change are intertwined. All of this has led to significant advances in our understanding of how housing and the life course and mobility are interconnected (see for example, Courgeau, 1985; Clark and Dieleman, 1996; Mulder, 2006, 2007; Billari and Liefbroer, 2007; Falkingham, et al., 2016).

In this reflection and review I provide observations on the evolution of research on residential mobility, that is, moves in the main within cities, and the links to the life course and housing selection on the one hand and on the intersection of mobility and neighborhoods on the other. I ask how has mobility research changed and developed, and what do we know about mobility and housing now, and what are the current foci in research on mobility. To organize the discussion I identify five themes in the studies of mobility:(1) the evolution of mobility from studies of the life cycle to studies of the life course, (2) the emerging attempts to forge a theory which incorporates the events of moving with the spells of staying, (3) the studies of outcomes of residential mobility, how the outcomes of moves create patterns of residential sorting and selection, (4) the extent to which neighborhoods and communities matter in the residential selection process and (5) the institutional context of residential mobility and neighborhood change. In the discussion I focus on local mobility and residential choice, which we can view as a subset of the larger theme of regional migration and "mobilities" more generally (Creswell, 2006). In exploring the five themes I draw largely on research examples from North America and the United Kingdom (where much of the literature has developed) but I do bring in studies which have used European, Canadian and Australian panel data. Research is developing rapidly in non-US contexts and will further enrich the findings reported in this review. In each section I discussion how mobility is the process which links housing choice to the housing market.

\section{Life cycle to life course}

Historically, the residential mobility literature can be traced to the studies by Stouffer (1940) and Rossi (1955). These studies set out to examine mobility 
behavior in metropolitan areas. Stouffer was interested in how distance played a role in behavior, and his contribution was to introduce the notion that we move in response to opportunities and specifically that our choice of how far to move is affected by the distribution of opportunities.

Distance is such an important factor that it needs more explicit study than it has received. Whether one is seeking to explain "why" persons go to a particular place to get jobs, ... to trade or "why" they marry the particular spouses they choose, the factor of spatial distance is of obvious significance. (Stouffer, 1940: 845)

His study of Cleveland (United States) asked about the role of an intervening opportunity. He set out a position which "hypothesized that the number of persons going a given distance is directly proportional to the opportunities at that distance and inversely proportional to the number of intervening opportunities" (Stouffer, 1940: 846). The Stouffer research has often been interpreted as a study of migration, but in fact it was a study of mobility in Cleveland using very detailed data of actual addresses and the moves between those addresses in the 1930s. The idea of examining distance was new to sociology and as he stated, was an important new way of thinking about behavior.

It was Rossi (1955) over a decade later in his study Why Families Move that extended the analyses of residential change from specific studies of distance to a whole range of questions about family mobility. ${ }^{1}$ In what has probably become the most quoted statement from the Rossi study, he identified the mobility generator as housing adjustment:

The findings of this study indicate the major function of mobility to be the process by which families adjust their housing to their housing needs that are generated by the shift in family composition that accompany life cycle changes (Rossi, 1955: 61)

In this statement we have an expression of the guiding notion that housing demand is translated into actual choice in the housing market by the process of residential moves within the city.

The Rossi study grew out of an analysis of residential change in Philadelphia and was part of a move in sociology to study the metropolis and urban life more generally. It was part of a turn to studying urban characteristics and especially the characteristics of small areas, and was driven by policy efforts to stabilize neighborhoods and increase the well-being of households. As the study developed and the data were analyzed, it became a study of how residential mobility linked a household's housing needs to the physical structure that the household occupied. Simply put, did the household have enough space and perhaps as importantly, the right kind of space? At the core of the Rossi investigation was the notion that at different stages of the life cycle a household had

1. See also Rossi's commentary in the reissue of his Why Families Move (1980). 
different needs, in particular for the amount of space. Thus, a household would be expected to move if they were not in equilibrium between their needs and the space they had available. In this way of thinking the stage in the family life cycle was in effect a determinant of the type of housing required. Also embedded in the thinking was that at certain points in what we now think of as the life course there was an association between size and type of household and the living space. There was also the notion that households change in a more or less regular way in response to the processes of births, deaths, marriages and divorces, and these changes accordingly affect the housing needs of families at different points in the life cycle. The life cycle then was the preeminent organizing framework of the early work on residential changes. But of course there is never a simple agreement about the stages of the lifecycle and the structure of the household. The use of age of the head and the size of household as explanatory factors for the life cycle was a simplification of what has turned out to be a complex process.

The emphasis, in the Rossi exploration, on the link between mobility and housing needs has motivated much of the research on the logic of mobility. From the perspective of Why Families Move it was all about the adjustment of housing space to housing needs. Households made decisions on their needs for space and quality of housing and location was a less primary motivation though from a geographical perspective the tradeoff between the house and its location was equally important. Naturally, from a sociological perspective it was about the stages in the evolutionary process of leaving the parental home, marriage and having children, and how housing needs changed with changes in family composition (Brown and Moore, 1970; Speare, 1970; Speare et al., 1974). Later, economists adapted the ideas of equilibrium behavior in housing needs as the motivating force for mobility (Hanushek and Quigley, 1978). The large body of research on tenure choice in economics, geography and demography also emerged from the ideas of homeownership in these early studies (see, for example, Ionnides, 1987; Haurin, 1991; Davies Withers, 1988 and Clark et al., 1994).

The notion of life cycle remained an important organizing framework for at least three decades after the original publication of Why Families Move. A substantial research literature explored the way in which the stage in the life cycle is linked to mobility and housing choices (Clark and Onaka, 1983; Odland and Shumway, 1993; Speare et al., 1974). The research on housing consumption and tenure choice focused on particular stages in the life cycle (Clark et al., 1984; Clark and Dieleman, 1996). However, what became obvious in the 1980s and 1990s was that the decisions about housing were no longer specifically keyed to particular stages in the life cycle. People were marrying later, or not marrying at all, and having children later, or not at all, and that the demographic processes which were once closely connected in a linear fashion to changes in household composition were becoming decoupled from age. The recognition that the household/housing link was much more dynamic than suggested by the static life cycle approach led to a growing literature on dynamics rather 
than statics. In response to the changes in family structures, research moved to a focus on the dynamics of mobility and housing choice rather than a static classification of people and houses (Clark and Dieleman, 1996; Clark, 2013a; Mulder 1993, 2007; Mulder and Smits, 1999; Helderman et al., 2006; Coulter et al., 2011; Coulter et al., 2015; Coulter and Scott, 2015).

\section{Life course perspectives}

Unlike lifecycle research that focused on the normative sequencing and timing of events, the life-course perspective emphasizes the variability in the number, timing and sequencing of events in parallel careers across people's lives, and in doing so draws attention to the variability and sometimes unpredictable nature of the life course (Rindfuss et al., 1987; Elder, 1985, 1998; Geist and McManus, 2008; Mulder, 1993; Clark and Dieleman, 1996; Lu, 1998). In addition, unpredictable moves called into question the utility of thinking in terms of orderly paths in the housing and occupational careers of families. While previously (in the 1950s and 1960s) marriage occurred in the early 20s and was rapidly followed by children and further housing career moves, now marriage takes place much later, or cohabitation may substitute marriage, and many households remain without children. Certainly the mean age when the first children is born is much later now than three decades ago. The average age of first-time mothers increased by 3.6 years, from 21.4 years in 1970 to 25.0 years in 2006 (Matthews and Hamilton, 2009).

The life course conceptualization focuses on how people transition through a variety of "states" and the way in which their moves are linked to specific changes in occupations (Huinink et al., 2014), relationships (Mulder and Smits, 1999), and addition and deletions to the family structure (Mulder and Wagner, 1998; Clark et al., 1994; Kulu, 2008; Kulu and Washbrook, 2014; Kley and Mulder, 2010). In the life course perspective it is specific occurrences which occur in the life course that are the triggering events which can stimulate residential change, but they may only be peripherally linked to age (Rabe and Taylor, 2010; Clark, 2013a, Warner and Sharp, 2016). Marriage always played a role in mobility (Mulder, 2003; Mulder and Wagner, 2001, 2012) but because separation and divorce were much less common at the time Rossi wrote, it is not surprising that there was less focus on family disruption although now we know that it is a fundamental force in the likelihood of residential change (Feijten, 2005; Dewilde, 2008, 2009) We also know that unanticipated events play important roles in relocation (DeGroot et al., 2011a, 2011b; Feijten and Mulder, 2010) and this is especially true in times of stress and market turmoil (Clark, 2013b; Clark, 2016; Ferreira et al., 2010).

When Rossi wrote Why Families Move there were few surveys and almost no panel studies but now panel surveys allow us to look at both moves and stays over very long periods of time, to trace the sequences of being a renter and an owner, and to provide a dynamic interpretation of residential change. It was panel data in the United States (PSID), Germany (GSOEP), the United King- 
dom (BHPS and Understanding Society) and later in Australia (The Housing Income and Labor Dynamics in Australia - HILDA) that made a shift to a life course approach possible. What these data sets provided was the events and their timing that define the life course. The longitudinal studies followed people and their marriages, the births, divorces, the new jobs, the entrances and exits from the labor market and how these events interacted with the housing stock (Mulder, 2006; Coulter and van Ham, 2013; Coutler et al., 2015). With panel data it has been possible to better interrogate the decision making process and how intentions are formed and translated into moves (DeGroot et al., 2011a; 2011b; Coulter et al., 2011; Clark and Lisowski, 2016), and to examine the changing nature of the outcomes of those moves. While we are establishing new models of the mobility decision-making process it is equally important to understand how the mobility process reflects the changing population composition of society at large. Mobility varies by the composition of the population - it is influenced by the age of the population, fertility and marriage decisions and by decisions in life contexts generally (Sage et al., 2014).

\section{Households, families and the life course in context}

We can see the turn to the life course in part as an outcome of the changing nature of families and population composition in the United States. The size, age and composition of households in developed economies is dramatically different than 50 years ago when Stouffer (1940) and Rossi (1955) first wrote about metropolitan neighborhoods. The new demographics include locally aging populations, postponed fertility and a younger foreign born immigrant population. Immigrants and their children are now more than 60 million people in the United States. Most Western European and North American populations also have rapidly increasing populations over 65 years of age, but at the same time an influx of young immigrants who are moving to take advantage of the economic opportunities available in the established economies of Europe and the United States. All of this changes the underlying mobility matrix from slowing mobility in general (Cooke, 2011, 2013) to decreasing mobility for aging populations (Morrison and Bryan, 2009), but at the same time increased mobility by young immigrant families (Clark, 2003). ${ }^{2}$

Now, near the end of the second decade of the $21^{\text {st }}$ century there are fewer families and fewer families with children than there were five or six decades ago. In 1960, family households made up almost two thirds of all households in the United States. Now family households make up slightly more than half of all households, but less than half of those households have children. This is a significant structural change in family composition with implications for mobility, fertility and neighborhoods (Table 1). In 1960 about $15 \%$ of men and $10 \%$ of women were never married, but by 2010 those percentages

2. There is a large literature on social mobility - movement across generations but I do not include these studies in this review. 
were $52 \%$ and $42 \%$. In general, Americans have become less likely to marry (although co-habitation has increased) and the average age at which women have their first child has increased steadily and total fertility has decreased with implications for mobility (Kulu and Washbrook, 2014).

The changing rates of marriage and the decreasing age when the first child is born directly affect mobility and housing consumption. This process of residential change and family formation is increasingly complex as family's juggle not only the fertility decision, but housing needs and labor force participation. As women have increased their participation in the labor force they are increasingly required to balance the competing demands of family formation and nurturing, and participating in the work force (Boyle et al., 2001; Cooke, 2001; LeClere and McLaughlin, 1997; Clark and Davies Withers, 1999, 2009; Clark and Huang, 2003). The increase in dual worker households further complicates the mobility process though more for migration than local moves (Cooke and Bailey, 1996; Cooke, 2001, 2003; Challiol and Mignonac, 2005; Lichter, 1980; Michelin et al., 2008; Jacobsen and Levin, 2000). In particular, changing fertility has direct implications for housing consumption and housing transitions. Clearly, a decline in fertility will decrease family size and by implication change housing needs (Kulu, 2008; Kulu and Washbrook, 2014; Kulu and Steele, 2013). There is both popular and academic literature which addresses the issue of how families deal with the costs of having and raising children and entering the housing market (see Forrest and Yip, 2013; Clapham et al., 2012).

With respect to family composition and family change, the role of mobility in the early years has been identified as a critical issue in understanding how young children are impacted by residential changes (Beck et al., 2016; Gambaro and Joshi, 2016). Frequent mobility generated by changes in family structures (separation or re-marriage), or persistent unemployment and unstable housing situations, often generates negative outcomes for children. As the authors of these papers note, it is the intersection of family vulnerability and related mobility which seems in combination to create the stress for both the family and young children. Whether there are long-term outcomes of frequent youthful mobility is still a topic of importance for studies of life course outcomes.

Thus far our discussion has privileged the issue of moving, of changing houses in response to changes in family composition as the life course unfolds. But we know that in any period there are many more who stay than move. Can

Table 1. The changing composition of US households

\begin{tabular}{cccc}
\hline & $\begin{array}{c}\text { Family Households } \\
\text { (millions) }\end{array}$ & $\begin{array}{c}\text { With Children<18 } \\
\text { (millions) }\end{array}$ & $\begin{array}{c}\text { Total Households } \\
\text { (millions) }\end{array}$ \\
\hline 1960 & $39.4(74.6 \%)$ & $24.2(45.8 \%)$ & 52.9 \\
2014 & $56.1(56.1 \%)$ & $22.1(21.0 \%)$ & 117.3 \\
\hline
\end{tabular}

Source: US Decennial Census and American Community Survey 
we link these processes - is there a way forward with an integrated approach to what is sometimes viewed as a dichotomous outcome?

\section{Moving and staying over the life course - attachment and duration}

It is not surprising that the first research on mobility was focused on the event of moving itself. Most of the surveys which examined whether or not someone moved (either a long distance migration or a short distance local move) were cross-sectional surveys at a single point in time which asked some form of the question "Have you moved in the past year?". As I discussed above, it was not until the development of panel surveys that it was possible to think about the sequence of moves and the timing between these moves. In some sense it is the shift to large-scale panel data sets which has allowed us to think about mobility as a continuum. In this sense mobility is simply one event which occurs infrequently over a very long time period. Much of the time it is years and often decades of stability in specific locations. Duration becomes the paramount state and is interrupted with moves created by choice or by necessity. By thinking of a continuum we are forced to recognize that events (moves) are simply points in a continuum of staying (Morrison and Clark, 2016).

Panel data afford us an entirely new and more fruitful conceptualization of human interactions with place. Now we can distinguish and characterize "stays" as units of analysis which also deserve study. From that perspective, moves are merely transitions between "stays" and we can now examine "stays" as well as moves. We can ask, is the stay temporary, that is, is it a move to deal with a current situation such as caring for an elderly parent or the pursuit of further education? Or is it a more enduring move, one which reflects a permanent employment situation - and associated with putting down roots such as becoming a homeowner? We can also ask, with panel data, what the length of stay is and what influences that duration (Thomas et al., 2016).

There was always interest in stayers, and in fact early research often juxtaposed movers and stayers as two separate populations. But we can see that of course they are not two different populations; rather, at various times people are movers and then stayers and so on. Functionally, the process is one which involves staying as the preferred state and moving as the process of achieving equilibrium (Morrison and Clark, 2016). This helps explain the emphasis (discussed in the previous section) on the decision making around the events which occur over the life course. By contextualizing mobility and migration within the broad framework of creating families and making decisions about where to work and where to live and in what kind of housing, we have an enriched structure which enables us to link decisions about partnering (and sometimes dissolving partnerships) and decisions about jobs and job locations (Helderman et al., 2004, 2006; Michelin et al., 2008; Kulu and Washbrook, 2014). In other words, the life course moves along in parallel streams in family composition, occupational choices and decisions about access to the urban environment broadly. Moves, either local or to another city or region come 
about as individuals progress along the life course. A marriage, a new job, the desire for larger housing are all linked to moves. Those moves are followed by periods (durations) in particular houses and places.

People move reluctantly because they are held in place by a myriad set of ties to people and places, near and not so near (Clark et al., 2015). Attachment is difficult to measure and has multiple dimensions but it does appear that family connections are important in the decision to stay rather than move. There are clearly benefits to be derived from residential stability (Oishi et al., 2007). Sometimes these are generated by simply wanting to be involved in the extended family, and sometimes from the requirements of helping with aging parents or grandchildren. The attachment to place is often identified as a broader sense of community where it is the links to friends and family in the same locality which creates what we can think of as communal belonging (Lewicka, 2010, 2011; Hidalgo and Hernandez, 2001). It is not that one necessarily spends time with the neighborhood community, but there is a sense of a safety net of friendship. As many studies have suggested, the willingness to do something for a neighbor is part of what we think of as social efficacy, or social connectedness. In contrast, the lack of social connectedness is created by high levels of residential turnover and greater individualism. The community has spatial as well as personal links (Uzzell et al., 2002; Grief, 2009; Woldoff, 2002; Clark et al., 2015). Although principally addressing mobility, Fischer and Malmberg (2001) and Hedman (2013) also note how place and family connections can influence the decision to move or not and if to move, whether to move nearby.

Previous research has shown directly that proximity matters for the relationship between parents and their adult children (Rogerson et al., 1993; Rogerson, 1996). Those papers demonstrate that the greater the likelihood of physical impairment (of older family members), the greater the likelihood of geographic convergence between elderly parents and their adult children. As these and other papers show, proximity can bring the generations closer and so increase the possibility of caregiving. Of course the possibility for help between adult children and parents can be reciprocal. Older parents can help their adult children with child care for grandchildren and other social contributions of time and sometimes resources (Mulder and Malmberg, 2014; Mulder and van der Meer, 2009). They can also help with inter-generational financial transfers (Mulder and Smits, 2013). Family networks are especially important in the southern countries of Europe, but others including Hickman (2010) and Hedman (2013) show their relevance as key factors in the decision to stay, especially when studying social classes where families can matter in their everyday life.

Elsewhere we have suggested that we might find a route to a linked model of moving and staying by using the concept of risk aversion (Morrison and Clark, 2016). In this conceptualization, households move and or stay depending on their risk propensity. People who are more risk averse are more likely to stay and to move less often. In contrast, people who are less risk averse may 
more easily perceive mobility as providing opportunities. From the perspective of risk, households who are thinking about moving evaluate the "risk" of adverse outcomes. In addition, the likelihood of making a particular choice varies for individuals depending on their past histories. This follows Kahneman's argument that the preference for the status quo is a consequence of loss aversion (Kahneman, 2011). Of course none of this adequately captures the moves that occur under duress, when the household simply has to move because of external events (Clark, 2016).

Several studies including those by Haurin and Gill (2002) and Kiel (1994) explore just how much mobility is slowed and duration increased in response to external events - in their case, changing house prices. Overall, increasing house prices do have the effect of slowing mobility and studies of subprime mortgage holders also suggest that those with high initial loan-to-value ratios are even more likely to stay. Households respond differently to external forces and in some cases staying is interrupted by these external events such as for those who entered the home owner market at the height of the housing price bubble. Some could not move and were forced to stay, while others lost their houses in mortgage foreclosure. Not all households respond the same way to these external shocks, but these events play a macro role in any study of moving and staying.

Although there are now some broad ideas about how to better link moving and staying, it is still not clear how we will create a unified model of moving and staying, but clearly that is an outcome which would bring an enriched understanding of just how moving or staying matters in the urban fabric ${ }^{3}$. And, because moves occur in the housing market, there is continuing interest in the way in which selection at the micro level affects patterns at the macro level, the outcomes of how people get sorted in space.

\section{Sorting and selection: People in places}

When households move they choose houses or apartments but they also choose the locations in which those dwellings are situated. These locations, the houses, apartments, condominiums and the whole vast range of housing types are typically grouped into neighborhoods and communities. Any particular house is part of a wider collection of often similar houses and invariably reflects common housing types, prices and even visual similarity. Thus, neighborhoods are spatial clusters of houses sometimes identified from within, but often identified from outside by using spatial boundaries, common markers and other visual clues of classification. Because the selection of a house is also the selection of a neighborhood and community, a substantial body of research asks why we make the choices we do and how much the places matter in our choices. The research also asks, what are the outcomes of those choices for the individual, and for the neighborhood (van Ham et al., 2008, 2012)? Neighborhoods are to

3. See Clark and Lisowski (2017) for a suggested approach to this problem. 
a greater or lesser extent part of our lives depending on our neighborhood and community attachment, and marketers have been adept at using the notion of community clustering to sell goods and services. Market research groups use detailed census data to create "clusters" of similar households who can be targeted by what we drive, what we read and what sort of entertainment we prefer. In a sense, residential areas can be seen as life style areas that offer (in a very broad sense) a particular brand of social life (Forrest, 2012). Now with the greater availability of digital data we can do more than just identify a particular place - we can easily view data on housing costs, residential turnover and measures of the quality of the neighborhood including such things as achievement scores for the local schools.

Households make choices, of houses and places, and the outcome of these choices across many individuals is to "sort" people by place. The sorting process is largely driven by differences in resources, but the sorting process also involves social status and preferences. It is not just resources, as we know that families prefer communities where there are other children, while young single adults want access to lively entertainment and likely will choose inner city areas where there are bars, nightclubs and other young people. Choosing and sorting is well documented both in the geographic studies (Clark and Fossett, 2008) and in psychology (Oishi et al., 2009; Oishi, 2010; Oishi et al., 2012). Less advantaged households are likely to seek areas with rental units, and resources in this instance will probably dictate the search area. Clearly, you will not search for housing in expensive single-family home neighborhoods if you cannot raise the funds for a down payment.

The higher the earnings and the greater the resources, the greater the set of opportunities that is available to the household or individual. At least at a superficial level there is an argument that poor people move into and within disadvantaged areas because they are poor (Cheshire, 2011; Clark et al., 2014). So, rich people live in advantaged areas because they have more resources. One interpretation of sorting and selection is to emphasize that the ability to exercise preferences depends on resources and in combination with status and ethnic preferences leads to patterns of homogeneity by class and race. If we combine the role of preferences and the persistency in the patterns of the housing stock, we obtain long-term patterns of income and status separation and they change only slowly. This view of the residential process fits clearly within an emphasis on choice but there is another perspective which emphasizes the constraints on the sorting process.

For low income and minority households, where to live in the housing market may be a much more constrained process. Constraints can arise in the housing choice process from the way in which lenders and banks behave in the housing market. To the extent that banks and mortgage lenders influence the resources available to households they have an impact on the choices that they can make. If those resources are provided selectively, that further limits the opportunities for particular groups, especially minorities (Gabriel and Rosenthal, 1991; Zorn, 1989; Wyly and Holloway, 2002). Discriminatory 
practices by real estate agents and individuals also impacts the selections within the urban mosaic though much less so than four decades ago.

There is a divide between those who see market actors as a major force in creating separation and segregation, and those who see the patterns as an outcome of resources. It is not in fact a choice between two interpretations, as resources clearly matter. But the alternative view does remind us that certainly in the past and to a lesser extent in the present, there are non-economic barriers to entry in communities and neighborhoods across cities. Even the studies which acknowledge the role of status argue that race is the critical variable in explaining residential patterns (Iceland et al., 2005) despite the substantial evidence of the complexity of the choice outcomes. The division between those who emphasized economic and preference explanations for separation and those who emphasized discriminatory actions in the housing market has created a contentious debate. That debate continues with strongly different versions of the evolution of the residential mosaic (see Clark, 2007 for a discussion of the different perspectives).

\section{Sorting, selection and segregation}

The evolution of the urban structure and the role of sorting was most clearly outlined in the Schelling (1971) interpretation of the process of clustering. At its heart, the Schelling model focuses on how very small differences in preferences can generate large differences in outcomes - large enough to provide distinct patterns by economic status, ethnicity and race. Schelling set out to understand why people get separated (sorted in the terminology here) and he drew on several anecdotes about how people choose housing. In his analysis, professors choose housing that they can afford, and we know that housing is somewhat clustered by price, and to the extent that a professor has a budget constraint and chooses to live where there are other professors, clustering as a natural outcome of choice will take place. In extending his argument, the central theme, perhaps less applicable to professors but certainly applicable for race and ethnicity, is that most groups wish to avoid being a minority in their neighborhood and Schelling shows that except for a 50:50 mixture no combination will be stable. It is the dynamics of moves, given slight (or strong preferences), to be with others of similar ethnicity or status which leads to patterns of clustering.

Since the initial statement, a plethora of studies have confirmed how small differences in preferences can generate strong patterns of separation by income, education and ethnicity even if we all desire integration (Zhang, 2004; Clark and Fossett, 2008). The finding that separation can exist in the residential fabric even if most people prefer integrated neighborhoods is important because it explains the continuing patterns of separation even in a world which is increasingly tolerant and where society has made major attempts to eliminate discrimination in the housing market. What we know now is that even without any discriminatory behavior in the housing market a slight preference for 
"like" neighbors can create significant levels of residential separation (sorting) as an outcome of mobility and cause it to persist. In other words, there are powerful forces at work to sort and to continue to sort populations by race, ethnicity and social status (Bailey, 2012; Clark and Morrison, 2012; Clark et al., 2014; Pais et al., 2009).

The finding that sorting is a fundamental process in the urban fabric, a process which is intimately connected to residential mobility, provides us with a link between the myriad moves that occur in any city and the underlying urban structure, and also a measure of how those structures change from the continuing process of residential relocation. The question which follows is how does place, the neighborhood, play a role in the sorting process, or in other words, how do neighborhoods matter?

\section{Neighborhoods and their role}

Earlier in the review I suggested that neighborhoods are simply the spatial clustering of somewhat similar residences. Of course identifying the neighborhood is no easy task - one person's neighborhood is not the same as another, though over time places have taken on identifications that are often a combination of general acceptance and wide recognition. It is not the purpose here to dwell on the identification process but rather to ask about if and how a place, the locality, we call a neighborhood matters in the residential sorting process. ${ }^{4}$

There is a distinct perception that neighborhoods should matter in people's lives. Where you live structures your access to urban services, your children's access to schools and provides levels of safely and urban amenities. Indeed, we are often defined by where we live and because our cities are divided by socio-economic status and that division has a spatial pattern we often use neighborhood terminology, sometimes ethnically based (Little Italy or Chinatown for example), as shorthand for a collection of neighborhood attributes. Even though there is now a voluminous body of research on "neighborhood effects" 5 the question remains - does the spatial context matter over and above the composition of the households within the spatial unit? And if it does matter, how important is it?

To continue the theme above, we feel that the place you live matters, certainly the facilities, schools, stores, churches and other amenities do affect daily living. Accessibility matters and the large body of literature on the journey to work emphasizes how separation between work and residence continues to influence urban structure. However, there is a continuing debate amongst those who argue that places affect outcomes across a range of dimensions but particularly relating to health and wellbeing.

4. There is a comprehensive discussion of potential neighborhood mechanisms which might drive neighborhood effects in Galster (2012).

5. See, for example, the volumes by van Ham et al. (2013) and Clapham et al. (2012). 
Certainly there is a substantial body of research which has documented the impacts and outcomes in disadvantaged neighborhoods (Hedman et al., 2015). In fact, a large body of work, especially by sociologists, has shown the way in which poor neighborhoods and minority and ethnic populations intersect (South and Crowder, 1997, South et al., 2005; 2011). The questions raised in these papers are how movement into and out of poor neighborhoods has long-term effects (Quillian, 2003; Crowder and South, 2005, 2008). A related question is whether households can escape these disadvantaged neighborhoods (Bailey and Livingston, 2008). Related to these studies are those that examine how ethnicity plays a role in the decisions to move and the decisions to stay (Crowder et al., 2012; Finney and Jivraj, 2013; South et al., 2005, 2011).

The focus on identifying neighborhood affects has a physical and a social dimension. Physically, at the environmental level, there is strong evidence that the place matters (see Ritz et al., 2000; Parker et al., 2005 for examples). To the extent that if the location is in a disadvantaged context (near polluting industries) then the locality does have an impact on the residents. Measuring the extent to which the health of a neighborhood population is poorer after controlling for age, education and other personal characteristics is at the heart of the neighborhood effects debate (Diez Roux, 2001 provides a detailed discussion of health and neighborhoods). At the same time, just because cancer is greater in a particular area or that longevity is lower does not mean that it is created by that location. There is a strong argument that the outcome is attributable to household composition. In short, people do not become poor by living in a particular place; rather a poor neighborhood is simply a function of the clustering of people who can only afford that location.

However, the research on the social structure of the neighborhood is an added dimension to our understanding of how neighborhoods work and how they may influence outcomes. Studies have shown that social cohesion (knowing and valuing your neighbors) and collective efficacy (community involvement and social networks) increase the positive value of a neighborhood (see for example, Cohen et al., 2008). By introducing social efficacy (the notion that community involvement, social networks and friendship ties are important elements of neighborhood quality), the research agenda goes beyond the physical characteristics and the individual family characteristics to the way in which social cohesion and shared values and expectations play a role in creating prosperous and sustainable communities (Paldam, 2000; Sampson et al., 1997).

A considerable body of the work on whether neighborhoods matter revolves around the intersection of the neighborhood and health outcomes (Diez Roux (2001) and on educational effects (Niewenhuis and Hooimeijer, 2016). The health research draws on the notion that neighborhood contexts may be related to health outcomes independently of individual level attributes. That said, the studies of health and neighborhoods which are discussed in Diez Roux and Mair (2010) provide a complex story about the links between people and places. They note that while health may be spatially patterned, the complexity of the linkages requires a myriad of strategies to uncover neighborhood health 
linkages. Amongst those strategies are recent studies which control for life course events and examine health outcomes (Brazil and Clark, 2017; Lippert, 2016). The search for good measures of just how much the neighborhood matters is an ongoing project. The causal argument is that individual health may benefit from one neighbor helping another in a time of need, or community health may benefit from the collective action of residents protesting the health risks of toxic waste coming from a nearby industrial facility.

A recent paper has re-examined the role of the neighborhood and educational outcomes using meta regression analysis (Niewenhuis and Hooimeijer, 2016) and concluded that there is a relationship between neighborhoods and individual educational outcomes. Students do less well in disadvantaged neighborhoods. In their review of the research they point to the role of neighborhood poverty, the proportion of ethnic/immigrant groups and social disorganization in the neighborhood. However, again while this is seemingly a relationship between people and place, it is also a function of the clustering of people of disadvantage. Are we measuring something about place or something about people? Only the measure of social disorganization is truly a measure of locality. Still, that clusters of poor and ethnically disadvantaged populations have poor educational outcomes is of considerable policy influence. The outcome reiterates our earlier discussion of how sorting creates the urban structure, often with negative outcomes for subsets of the population at large.

Just how much the neighborhood matters is still debated, and assessing the independent effect of the neighborhood is still a difficult task. Only a few studies provide an estimate of the additive neighborhood contribution to a specified outcome. A study by Datcher (1982) put the value at 25 percent attributable to the neighborhood, but a study by Nicoletti and Rabe (2012) attributed about 10-15 percent of the difference in educational outcomes to neighborhood effects. Studying the likelihood of mobility, Clark and Ledwith (2007) suggest that less than 5 percent of the explanation for the likelihood of moving can be attributed to neighborhood characteristics. It does appear that there are neighborhood effects across a wide range of outcomes, but the effects may best be identified as occurring at the margin rather than as the primary explanation for localized outcomes in education, mobility, health and deviant behavior.

\section{Institutions, policy and mobility}

Residential mobility does not occur in a vacuum, it occurs within a political framework, an economic setting and set of institutional rules and guidelines, and these contexts are different over time and across national contexts. In one sense mobility is not very different in the European context of the welfare state than it is in the (relatively) less regulated housing market of the United States. On the one hand, people move with the same motivations and resource limits in those different societies. But on the other hand, there are very different policy aims, institutional constraints and housing supply forces across Europe 
and in the US, Australia, New Zealand and Canada. Thus, to understand fully the mobility process and its outcomes it is also necessary to understand the context within which it occurs.

Families move to improve their housing whether they are in Germany, Spain, Italy or the United States. The recurring expression of the desire to own a home varies only a little across national contexts. However, it is a complex interaction between the individual and the housing market, and the outcome takes on different forms in different social and economic environments even though the motivations may be similar. The housing opportunity set is very different in the Spanish and Italian contexts; for example, where homeownership is amongst the highest in the developed world, and where large proportions of the housing stock are multi-family units, than it is in the large cities in the United States where single-family dwellings still predominate.

\section{Housing as context}

From the perspective of this review, housing is the context within which choice and mobility occur, but the choices and the ability to move are conditioned by financial institutions and government policies. Interest rates matter in whether households will move to ownership, and boom and bust cycles in housing affect the ability to sell and buy houses as we saw in the General Financial Crisis (GFC). The housing sector is central in all advanced economies and is increasingly important in developing economies also. In many countries housing makes up the largest component of wealth. In the United States real estate accounts for roughly a third of the total assets held by the nonfinancial private sector, and the majority of households still tend to hold wealth in the form of their homes rather than in financial assets.

It is in institutions that issues about housing provision and housing access meet (see Ronald and Elsinga, 2012 and Ronald, 2008). The approaches to the questions of housing provision and housing access in different national contexts reflect different conceptions of the housing market, and reflect quite different philosophical approaches to how society should be organized. Within those conceptions, European welfare societies have tended to focus on housing access more generally, and they have privileged supply side approaches to the housing market, with important building programs undertaken by such groups as the housing corporations in the Netherlands (Priemus, 2012) and similar programs in the Scandinavian countries. Underlying the European approach to the provision of housing is the social welfare argument that the state should promote a defined minimum provision of housing at a defined affordable price and that the state should overcome shortages of affordable housing (Yates, 2012).

The path to housing provision has been quite different in the United States with a much greater focus on the market and individual actors. However, as Yates (2012) notes, the implicit US subsidies (tax concessions for homeowners) which do not involve any explicit budgetary outlay) in effect is a way of 
subsidizing or supporting one group versus another (Yates, 2012). In the social welfare nations, the tendency has been to use explicit subsidies and to encourage the availability of social rented housing, while in the liberal economies the tendency has been to favor implicit subsidies (for homeowners especially) more than the explicit subsidies.

The discussion of housing supply is further complicated by the fact that both private and government institutions are intimately involved with housing and housing provision. On the private side, house building from plot to product is time-consuming and imposes varying and complex costs. The process requires substantial capital and often highly leveraged enterprises with high levels of risk over considerable periods of time. Where once individual houses were constructed by local builders, much of the housing provision is now in the hands of large companies and their integrated processes, because these are the corporations which have the capital, organizational structure and motivation to build. At the institutional level, house building is a highly regulated industry with guides and rules coming both from land-use planning and local governments.

Thus, housing is at one and the same time an individual market commodity and a public good which has increasingly involved state oversight including broad environmental regulations of where building can occur, as well as local rules about what can be built and where it can be built. In this sense housing is a trade-off between individual consumer preferences (the size, style and type of housing and where it is located) and a builder's perception of what can be sold. That intersection is at the heart of the housing market. In the more privatized markets of the United States and similar national contexts, housing is much more likely to be the outcome of consumer preferences (the current increase in the absolute size of houses in the US is a good example of the role of consumer preferences), whereas in several European contexts the powerful role of housing providers to build smaller and multifamily units changes the opportunity set in the market. State and local intervention changes the supply, the opportunity set, but not the choice processes.

\section{Access to housing}

In Europe, there has been a concerted program of both building affordable housing and subsidizing the costs of this housing for lower income populations. In the Netherlands, for example, the relatively tight controls of what can be built (though somewhat relaxed in the last decade) have also been directed to created mixing housing communities where housing is available across the income spectrum. In contrast, the US has built less subsidized housing but moved to direct assistance to lower income families in the moving process. There are now about 2.1 million housing vouchers in the US which can be used by the recipient to choose rental housing in apartment complexes which accept these government subsidies. The housing voucher program is the major US government program to help house low-income families, the elderly and 
the disabled, and to provide access to affordable, safe and sanitary housing in the private market. The US approach, in contrast to the Dutch approach, is to provide assistance so that individuals search for and locate their own housing. In other words, they engage in residential mobility similar to households in the private sector but with subsidies and constraints to the extent that they must find housing where their subsidy will be accepted.

The Moving to Opportunity program (MTO) was an experimental approach to providing housing access for low-income populations and demonstrated some gains for those who were able to move from inner city disadvantaged neighborhoods to lower poverty neighborhoods (Ludwig et al., 2012). ${ }^{6}$ The average gains in some health outcomes were notable but often the average gains were not repeated across different geographical contexts and often pertained only to subsets of the MTO population (Clark, 2008). It is difficult to intervene in a market-driven housing economy as the MTO program discovered. In fact, what the MTO research reiterated is that many moves are to nearby neighborhoods and often even return moves to the original locations. Familiar places often attracted respondents back to their old neighborhoods.

How homeownership can, or should be provided, has generated an important literature which while not directly connected to residential mobility, has implications for who can move and where mobility is possible (Ronald, 2008; Forrest and Yip, 2013). These studies and a parallel literature in economics (Wood and Ong, 2011; Diaz and Luengo-Prado, 2008, 2013) examine the question of whether homeownership will be sustainable for urban populations as a whole. It is indeed possible that the long period of homeownership growth during the $20^{\text {th }}$ century may not be replicated in the $21^{\text {st }}$ century. Technical changes, flexible labor markets and less stable employment may challenge the previous thinking of smooth paths to ownership. The surge in housing prices globally and stagnating wages may make ownership only available for the top quintile of earners. Whether there will be a concurrent increase in renting and churning in the housing market is a possibility of growing instability in housing markets. And, the other issue is whether a bifurcated ownership process with wealthier owners and poorer renters will contribute to growing societal inequality.

\section{Observations and the future research agenda on residential mobility}

The subsets of questions about mobility and the housing market that I have explored in this review and discussion are still at the cutting edge of research on mobility and housing. Within each of the topics - life course processes, linking moving and staying, sorting and selection, neighborhood effects and institutional contexts - there are still important and unresolved questions of how families make decisions (Steele et al., 2013), about where to live and the ensuring implications for mobility; how the sorting process is evolving and the implications for

6. See also the extensive literature on the MTO project discussed in Ludwig et al. (2012) and in Clark (2008). 
segregation; how much neighborhoods matter in the mobility process; and how affordability and housing costs are influencing mobility decisions.

The discussions of partnering and the organization of family structures, and in turn how they influence housing choices, are the focus of studies in Europe and the United States. Although the specific interests vary, there are common questions about how millennials will access the housing market, whether transfers of wealth from parents to children will exacerbate inequality and how the aging population will be housed. Changing fertility patterns, decreasing household size and intergenerational links between elderly parents, adult children and grandchildren all have implications for residential mobility and neighborhood change.

Sorting and segregation is an ongoing process in the urban fabric and the way in which these patterns will change is a direct outcome of residential choices. What goes into these choices and how much of the patterns of separation can be explained by sorting choices is a continuing research topic with quite different concerns across the social sciences. Will the patterns change with the residential choices of young adults entering the housing market, will racial and ethnic patterns continue to segregate or will mixed race households change the patterns of segregation?

The review of neighborhood/mobility interactions stressed how far we have to go to understand the role of neighborhoods and thus far we are some distance from estimating how and in what way neighborhoods impact mobility. They clearly are part of the search and selection process but we need models which relate choice to neighborhood characteristics. There is also a continuing focus on disadvantaged neighborhoods and their impact on outcomes. But while we can point to the problems of disadvantaged neighborhoods, there has been little if any advance on solutions to poverty concentrations, and the use of vouchers to move populations across the urban fabric has had mixed success.

Housing costs, affordability and access continue to be major social issues and are central to understanding the intersection of mobility and housing. Only now are we beginning to ask questions about the impact of implicit subsidies that have grown up around homeownership in the United States. The two sides of the mirror reflect the high housing costs, accessible by the top quintile of earners and of limited affordability for minority households, and are thus reflected in the widening gap between the wealthy and poorer (often minority) households. The recent decade of housing boom and bust and the subprime crisis in the US pushed to the front the recognition of the way in which housing interacts with the economy in general, and how it played a major role in the general financial crisis.

The field of residential mobility and residential selection is central to understanding the continuing evolution of the urban mosaic. There are important unresolved questions to be answered and cross-cultural comparisons to explore. This review has reviewed the current literature to set up a framework for a continuing discussion of residential mobility and urban change. 


\section{Bibliographic references}

BAILEY, Nick (2012). "How Spatial Segregation Changes Over Time: Sorting Out the Sorting Process." Environment and Planning A, 44, 705-722. <https://doi.org/10.1068/a44330>

Bailey, Nick and Livingston, Mark (2008) "Selective Migration and Neighborhood Deprivation: Evidence from 2001 Census Migration Data for England and Scotland." Urban Studies, 45, 943-961. <https://doi.org/10.1177/0042098007088475>

Beck, Brenden, ButTaro, Anthony and Lennon, Mary Clare (2016) "Home Moves and Child Wellbeing in the First Five Years of Life in the US." Longitudinal and Life Course Studies, 7 (3), 240-264. $<$ https://doi.org/10.14301/llcs.v7i3.374>

Billari, Francesco and Liefbroer, Aart (2007). "Should I Stay or Should I Go: The Impact of Age Norms on Leaving Home.” Demography, 44, 181-198. <https://doi.org/10.1353/dem.2007.0000>

Boyle, Paul, Cooke, Thomas, Halfacree, Keith and Smith, Darren (2001). "A Cross-National Comparison of The Impact of Family Migration on Women's Employment Status." Demography, 38, 201-213. <https://doi.org/10.1353/dem.2001.0012>

Brazil, Noli and Clark, William A.V. (2017) "Individual Mental Health, Life Course Events and Dynamic Neighbourhood Change During the Transition to Adulthood." Health and Place, 45, 99-109. <https://doi.org/10.1016/j.healthplace.2017.03.007>

Brown, Lawrence A. and Moore, Eric G. (1970). "The Intra-Urban Migration Process: A Perspective." Geografiska.Annaler B, 52, 1-13. <https://doi.org/10.2307/490436>

Challiol, Helene and Mignonac, Karim (2005). "Relocation Decision-Making and Couple Relationships: A Quantitative and Qualitative Study of Dual-Earner Couples." Journal of Organizational Behavior, 26, 247-274. <https://doi.org/10.1002/job.311>

Cheshire, Paul (2012). "Are Mixed Community Polices Evidence Based? A Review of the Research on Neighborhood Effects." In: VAN HaM, Maarten, ManleY, David, Bailey, Nick, Simpson, Ludi and Maclennan, Duncan (eds.). Understanding Neighborhood Dynamics and Neighborhood Effects Research: New Perspectives Dordrecht (NL): Springer. <https://doi.org/10.1007/978-94-007-2309-2_12>

Clapham, David; Clark, William A. V. and GibB, Kenneth (2012). Sage Handbook of Housing Studies. London: Sage Publications.

Clark, William A. V. (2003) Immigrants and the American Dream. New York: Guilford.

- (2007) "Race, Class and Place: Evaluating Mobility Outcomes for African Americans." Urban Affairs Review, 42, 295-314. <https://doi.org/10.1177/1078087406292531>

- (2008) "Re-Examining the Moving to Opportunity Study and its Contribution to Changing the Distribution of Poverty and Ethnic Concentration." Demography, 45, 515-535. <https://doi.org/10.1353/dem.0.0022>

- (2013a). "Life Course Events and Residential Change: Unpacking Age Effects on the Probability of Moving." Journal of Population Research, 30, 319-334. <https://doi.org/10.1007/s12546-013-9116-y> 
- (2013b). "The Aftermath of the General Financial Crisis for the Ownership Society: What Happened to Low Incomes Households in the United States." International Journal of Housing Policy, 13, 227-246.

<https://doi.org/10.1080/14616718.2013.796811>

- (2016). "Life Events and Moves Under Duress: Disruption in the Life Course and Mobility Outcomes." Longitudinal and Life Course Studies, 7 (3), 218-239. <https://doi.org/10.14301/llcs.v7i3.376>

Clark, William A. V. and Davies Withers, Suzanne (1999). "Changing Jobs and Changing Houses: Mobility Outcomes of Employment Transitions.” Journal of Regional Science, 39, 653-673.

<https://doi.org/10.1111/0022-4146.00154>

- (2007). "Family Migration and Mobility Sequences in the United States: Spatial Mobility in the Context of the Life Course." Demographic Research (Max Planck Institute for Demographic Research), 17 (20), 591-622.

$<$ https://doi.org/10.4054/DemRes.2007.17.20>

- (2009). "Fertility, Mobility and Labor Force Participation: A Study in Synchronicity." Population Space and Place, 15, 305-321.

$<$ https://doi.org/10.1002/psp.555>

Clark, William A. V., Deurloo, Marinus. C. and Dieleman, Francois, M. (1994). "Tenure Changes in the Context of Micro-Level Family and Macro Level Economic Shifts." Urban Studies, 31, 137-154.

<https://doi.org/10.1080/00420989420080081>

Clark, William A. V. and Dieleman, Francois, M. (1996). Households and Housing: Choice and Outcomes in the Housing Market. Rutgers, State University of New Jersey, Center for Urban Policy Research.

Clark, William A. V., Dieleman, Francois M. and Deurloo, Marinus (1984). "Housing Consumption and Residential Mobility." Annals of the Association of American Geographers, 74, 29-43. <https://doi.org/10.1111/j.1467-8306.1984.tb01432.x>

Clark, William A.V., Duque-Calvache, Ricardo and Palomares-Linares, Isabel (2015). "Place Attachment and the Decision to Stay in the Neighborhood." Population Space and Place, 23 (2). <https://doi.org/10.1002/psp.2001>

Clark, William A. V. and FosSETT, Mark (2008). "Understanding the Social Context of the Schelling Segregation Model." Proceedings of the National Academy of Sciences, 105, 4109-4114. <https://doi.org/10.1073/pnas.0708155105>

Clark, William A. V. and HuAng, Youqin (2003). "The Life Course and Residential Mobility in British Housing Markets." Environment and Planning A, 35, 323-339. <https://doi.org/10.1068/a3542>

Clark, William A. V. and Ledwith, Valerie (2007). "How Much Does Income Matter in Housing Choice?" Population Research and Policy Review, 26, 145-161. <https://doi.org/10.1007/s11113-007-9026-9>

Clark, William A. V. and Lisowski, William (2016). "Decisions to Move and Decisions to Stay: Life Course Events and Mobility Outcomes.” Housing Studies, Online 20 July 2016. $<$ https://doi.org/10.1080/02673037.2016.1210100>

- (2017). "Prospect Theory and the Decision to Move or Stay." Proceedings of the National Academy of Sciences, 114 (36), E7432-E7440. <https://doi.org/10.1073/pnas.1708505114> 
Clark, William A. V. and Morrison, Philip S. (2012). "Socio-Spatial Mobility and Residential Sorting: Evidence from a Large Scale Survey”. Urban Studies, 49, 3253-3270. <https://doi.org/10.1177/0042098012442418>

Clark, William A. V. and OnAKA, Jun (1983). "Life Cycle and Housing Adjustment as Explanations of Residential Mobility." Urban Studies, 20, 47-57. <https://doi.org/10.1080/713703176>

Clark, William A.V., van Ham, Maarten and Coulter, Rory (2014). "Spatial Mobility and Social Outcomes." Journal of Housing and the Built Environment, 29 (4), 699-727. <https://doi.org/10.1007/s10901-013-9375-0>

Cohen, Deborah, Inagami, Sanae and Finch, Brian (2008). "The Built Environment and Collective Efficacy." Health and Place, 14, 198-208. <https://doi.org/10.1016/j.healthplace.2007.06.001>

CoOKe, Thomas J. (2001). “'Trailing Wife' or 'Trailing Mother'? The Effect of Parental Status on the Relationship between Family Migration and the Labor-Market Participation of Married Women.” Environment and Planning A, 33, 419-430. <https://doi.org/10.1068/a33140>

- (2003). "Family Migration and the Relative Earnings of Husbands and Wives." Annals of the Association of American Geographers, 93, 338-349. <https://doi.org/10.1111/1467-8306.9302005>

- (2011). "It is not Just the Economy: Declining Migration and the Rise of Secular Rootedness." Population, Space and Place, 17, 193-203. <https://doi.org/10.1002/psp.670>

- (2013). "Internal Migration in Decline." The Professional Geographer, 65, 664-675. <https://doi.org/10.1080/00330124.2012.724343>

Cooke, Thomas, J. and Bailey, Adrian, J. (1996). "Family Migration and the Employment of Married Women and Men.” Economic Geography, 72, 38-48. <https://doi.org/10.2307/144501>

COURGEAU, Daniel (1985). "Interaction between Spatial Mobility, Family and Career Life Cycle: A French Survey.” European Sociological Review, 1, 139-162. <https://doi.org/10.1093/oxfordjournals.esr.a036382>

COUlTER, Rory and SCOTT, Jacqueline (2015). "What Motivates Residential Mobility? Re-Examining Self- Reported Reasons for Desiring and Making Residential Moves." Population, Space and Place, 21, 354-371. <https://doi.org/10.1002/psp.1863>

Coulter, Rory and van Ham, Maarten (2013). "Following People Through Time: An Analysis of Individual Residential Mobility Biographies." Housing Studies, 28 (7), 1037-1055. <https://doi.org/10.1080/02673037.2013.783903>

Coulter, Rory; van Ham, Maarten and Feijten, Peteke (2011). "A Longitudinal Analysis of Moving Desires, Expectation and Actual Moving Behavior.” Environment and Behavior A, 43, 2742-2760. <https://doi.org/10.1068/a44105>

- (2012). "Partner Disagreement in Moving Desires and the Subsequent Moving Behavior of Couples." Population Space and Place, 18, 16-30. <https://doi.org/10.1002/psp.700>

Coulter, Rory, van Ham, Maarten and Findlay, Alan M. (2015). "Re-thinking Residential Mobility: Linking Lives Through Time and Space.” Progress in Human Geography, 1-23. <https://doi.org/10.1177/0309132515575417> 
Cresswell, Tim (2006). On the Move: Mobility in the Modern Western World. Routledge: New York.

Crowder, Kyle, Pais, Jeremy and South, Scott, J, (2012). "Neighborhood Diversity, Metropolitan Constraints, and Household Migration.” American Sociological Review, 77, 325-353. <https://doi.org/10.1177/0003122412441791>

Crowder, Kyle and South, Scott J. (2005). "Race, Class, and Changing Migration Patterns between Poor and Nonpoor Neighborhoods." American Journal of Sociology, 110 (6), 1715-1763.

<https://doi.org/10.1086/428686>

- (2008). "Spatial Dynamics of White Flight: The Effects of Local and Extralocal Racial Conditions on Neighborhood Out Migration." American Sociological Review, 73 (5),792-812. <https://doi.org/10.1177/000312240807300505>

DATCHER, Linda (1982). "Effects of Community and Family Background on Achievement." The Review of Economics and Statistics, 64, 32-41. <https://doi.org/10.2307/1937940>

Davies Withers, Suzanne (1998). "Linking Household Transitions and Housing Transitions: A Longitudinal Analysis of Renters." Environment and Planning A, 30, 615-630. <https://doi.org/10.1068/a300615>

De Groot, Carola, Mulder, Clara and Manting, Dorien (2011a). "Intention to Move and Actual Housing Behavior.” Housing Studies, 26, 307-328. <https://doi.org/10.1080/02673037.2011.542094>

De Groot, Carola, Mulder, Clara; Das, Marjolijn and Manting, Dorien (2011b). "Life Events and the Gap between Intention to Move and Actual Mobility." Environment and Planning $A$, 43, 48-66. <https://doi.org/10.1068/a4318>

DEWILDE, Carolina (2008). "Divorce and the Housing Movements of Owner-Occupiers: A European Comparison.” Housing Studies, 23 (6), 809-832. $<$ https://doi.org/10.1080/02673030802423151>

- (2009). "Divorce and Housing: A European Comparison of the Housing Consequences of Divorce for Men And Women." In: ANDRESS, Hans-Jurgen and HuMMELSHEIM, Dina (eds.) When Marriage Ends. Economic and Social Consequences of Partnership Dissolution. Cheltenham, UK: Edward Elgar Publishing. <https://doi.org/10.4337/9781848447202.00019>

DiaZ, Antonia and Luengo-Prado, Maria (2008). "On the User Cost of Homeownership." Review of Economic Dynamics, 11, 584-613. <https://doi.org/10.1016/j.red.2007.12.002>

- (2013). "Homeownership: Economic Benefits." In: Smith, Susan, J., Elsinga, Marja, Fox-O’Mahony, Lorna, Ong, Seow and Wachter, Susan (eds.). The International Encyclopedia of Housing and Home. Amsterdam: Elsevier. <http://www.luengoprado.net/pdfs/benefits.pdf>

Diez Roux, Ana (2001). "Investigating Neighborhood and Area Effects on Health." American Journal of Public Health, 91 (11), 1783-89. <http://hdl.handle.net/2027.42/78995>

Diez Roux, Ana and MaIr, Christina (2010). "Neighborhoods and Health." Annals New York Academy of Sciences, 1186, 125-145. <https://doi.org/10.1111/j.1749-6632.2009.05333.x> 
Elder, Glen (1985). Life Course Dynamics: Trajectories and Transitions 1968-1980. New York: Cornell University Press.

- (1998). "The Life Course as Development Theory." Child Development, 69,1-12 <https://doi.org/10.1111/j.1467-8624.1998.tb06128.x>

Falkingham, Jane, Sage, Joe, Stone, Julia and Vlachantoni, Athina (2016). "Residential Mobility Across the Life Course: Continuity and Change Across Three Cohorts in Britain." Advances in Life Course Research, 30, 111-123.

<https://doi.org/10.1016/j.alcr.2016.06.001>

FeIJTEN, Peteke (2005). "Union dissolution, unemployment and moving out of homeownership.” European Sociological Review, 21, 59-7.

<https://doi.org/10.1093/esr/jci004>

Feijten, Peteke and Mulder, Clara (2010). "The Timing of Household Events and Housing Events in the Netherlands: A Longitudinal Perspective." Housing Studies, 17 (5), 773-792. <https://doi.org/10.1080/0267303022000009808>

Ferreira, Fernando, Gyourko, Joseph and Tracy, Joseph (2010). "Housing Busts and Housing Mobility." Journal of Urban Economics, 68, 34-45. <https://doi.org/10.1016/j.jue.2009.10.007>

Finney, Nissa and Jivraj, Stephen (2013). "Ethnic Group Population Change and Neighbourhood Belonging." Urban Studies, 50, 3323-3341. <https://doi.org/10.1177/0042098013482497>

Fischer, Peter and Malmberg, Gunnar (2001). "Settled People Don't Move: On Life Course and (Im-) Mobility in Sweden." Population Space and Place, 7, 357-371. $<$ https://doi.org/10.1002/ijpg.230>

Forrest, Ray (2012). "Housing and Social Life.” In: Clapham, David, Clark, William A. V. and GibB, Kenneth (eds.). The Sage Handbook of Housing Studies. London: Sage. <https://doi.org/10.4135/9781446247570.n17>

FOrRest, Ray and YIP, Ngai (2013). Young People and Housing: Transitions Trajectories and Generational Fractures. London: Routledge.

Gabriel, Stuart and Rosenthal, Stephen (1991). "Credit Rationing, Race and the Mortgage Market." Journal of Urban Economics, 29, 371-379. <https://doi.org/10.1016/0094-1190(91)90007-T>

Galster, George. (2012). "The Mechanism(s) of Neighbourhood Effects: Theory, Evidence, and Policy Implications.” In: van Ham, Maarten, Manley, David, BAILEY, Nick, Simpson, Ludi and Maclennan, Duncan (eds.). Neighbourhood Effects Research: New Perspectives. Dordrecht, NL: Springer. <https://doi.org/10.1007/978-94-007-2309-2_2>

Gambaro, Ludovica and Joshi, Heather (2016). "Moving Home in the Early Years: What Happens to Children in the UK." Longitudinal and Life Course Studies, 7 (3), 265-287. <https://doi.org/10.14301/llcs.v7i3.375>

GeIST, Claudia and MCMAnus, Patricia (2008). "Geographical Mobility over the Life Course: Motivations and Implications." Population Space and Place, 14, 283-303. <https://doi.org/10.1002/psp.508>

GrEIF, Meredith. J. (2009). "Neighborhood Attachment in the Multiethnic Metropolis." City \& Community, 8, 27-45. <https://doi.org/10.1111/j.1540-6040.2009.01268.x> 
HanuscheK, Eric and Quigley, John (1978). "An Explicit Model of Intra-Metropolitan Mobility.” Land Economics, 54, 411-429. $<$ https://doi.org/10.2307/3146168>

Haurin, Donald R. (1991). "Income Variability, Homeownership, and Housing Demand." Journal of Housing Economics, 1 (1), 60-74. <https://doi.org/10.1016/S1051-1377(05)80025-7>

Haurin, Donald and Gill, H. Leroy (2002). "The Impact of Transaction Costs and the Expected Length of Stay on Homeownership." Journal of Urban Economics, 51, 563-584. <https://doi.org/10.1006/juec.2001.2258>

Hedman, Lina (2013). "Moving Near Family? The Influence of Extended Family on Neighbourhood Choice in an Intraurban Context." Population, Space and Place, 19 (1), 32-45. <https://doi.org/10.1002/psp.1703>

Hedman, Lina; Manley, David; van Ham, Maarten and Osth, John (2015). "Cumulative Exposure to Disadvantage and the Intergenerational Transmission of Neighbourhood Effects." Journal of Economic Geography, 15, 195-215. $<$ https://doi.org/10.1093/jeg/lbt042>

Helderman, Armanda C., Mulder, Clara and van Ham, Maarten (2004). "The Changing Effect of Home Ownership on Residential Mobility in the Netherlands, 1980-98." Housing Studies, 19 (4), 601-616. <https://doi.org/10.1080/0267303042000221981>

Helderman, Amanda C., van Ham, Maarten and Mulder, Clara (2006). "Migration and Home Ownership." Tijdschrift voor Economische en SocialeGeografie, 97,111-125. <https://doi.org/10.1111/j.1467-9663.2006.00506.x>

Hidalgo, M. Carmen and HernándeZ, Bernardo (2001). "Place Attachment: Conceptual and Empirical Questions." Journal of Environmental Psychology, 21, 273-281. <https://doi.org/10.1006/jevp.2001.0221>

HiCKMAN, Paul (2010). Understanding Residential Mobility and Immobility in Challenging Neighbourhoods. Research Paper 8. CRESR, Sheffield Hallam University: Sheffield.

HuininK, Johannes, Vidal, Sergi and KleY, Stefanie (2014). "Individuals' openness to migrate and job mobility." Social Science Research, 44, 1-14. <https://doi.org/10.1016/j.ssresearch.2013.10.006>

ICEland, John, Sharpe, Cicely and Steinmetz, Erica (2005). "Class Differences in African American Residential Patterns in US Metropolitan Areas 1990-2000.” Social Science Research, 34, 252-266. <https://doi.org/10.1016/j.ssresearch.2004.02.001>

IoAnNides, Yannis (1987). "Residential Mobility and Housing Tenure Choice." Regional Science and Urban Economics, 17, 265-287. <https://doi.org/10.1016/0166-0462(87)90050-0>

JACOBSEN, Joyce P. and LEVIN, Laurence (2000). "The Effects of Internal Migration on the Relative Economic Status of Women and Men." Journal of Socio-Economics, 29 (3), 291-304. <https://doi.org/10.1016/S1053-5357(00)00075-5>

KAHNEMAN, Daniel (2011). Thinking Fast and Slow. New York: Farrar Straus and Girroux KIEL, Katherine (1994). "The Impact of Housing Price Appreciation on Household Mobility." Journal of Housing Economics, 3 (2), 92-108. <https://doi.org/10.1006/jhec.1994.1002> 
Kley, Stephanie and Mulder, Clara (2010). "Considering, Planning, and Realizing Migration In Early Adulthood. The Influence of Life-Course Events and Perceived Opportunities on Leaving the City in Germany." Journal Housing and the Built Environment, 25, 73-94. <https://doi.org/10.1007/s10901-009-9167-8>

Kulu, Hill (2008). "Fertility and Spatial Mobility in the Life Course, Evidence from Austria." Environment and Planning A, 40, 632-652. <https://doi.org/10.1068/a3914>

Kulu, Hill and STEELE, Fiona (2013). "Interrelationship between Child Bearing and Housing Transitions in the Life Course.” Demography, 50, 1687-1714. <https://doi.org/10.1007/s13524-013-0216-2>

Kulu, Hill and WashbroOK, Elizabeth (2014). "Residential Context, Migration and Fertility in a Modern Urban Society." Advances in Life Course Research, 21, $168-182$. <https://doi.org/10.1016/j.alcr.2014.01.001>

LeClere, Felicia B. and McLaughlin, Diane, K. (1997). "Family Migration and Changes in Women's Earnings: A Decomposition Analysis." Population Research and Policy Review, 16, 315-35. <https://doi.org/10.1023/A:1005781706454>

LEWICKA, Maria (2010). "What Makes Neighborhood Different from Home and City? Effects of Place Scale on Place Attachment." Journal of Environmental Psychology, 30 (1), 35-51. <https://doi.org/10.1016/j.jenvp.2009.05.004>

- (2011). "Place Attachment: How Far Have We Come in the Last 40 Years?" Journal of Environmental Psychology, 31 (3), 207-230. <https://doi.org/10.1016/j.jenvp.2010.10.001>

LichTER, Daniel (1980). "Household Migration and Labour Market Position of Married Women.” Social Science Research, 9, 83-97. <https://doi.org/10.1016/0049-089X(80)90010-1>

Lippert, Adam M. (2016). "Stuck in Unhealthy Places: How Entering, Exiting, and Remaining in Poor and Nonpoor Neighborhoods is Associated with Obesity during the Transition to Adulthood." Journal of Health and Social Behavior, 57, 1-21. <https://doi.org/10.1177/0022146515627682>

Lu, Max (1998)."Analyzing Migration Decision Making: Relationships between Residential Satisfaction, Mobility Intentions, and Moving Behavior." Environment and Planning A, 30, 1473-1495. <https://doi.org/10.1068/a301473>

Ludwig, Jens, Duncan, Greg J., Gennetian, Lisa A., Katz, Lawrence F., Kessler, Ronald C., Kling, Jeffrey R. and Sanbonmatsu, Lisa (2012). "Neighborhood Effects on the Long-Term Well-Being of Low-Income Adults." Science, 337 (6601), 1505-1510. <https://doi.org/10.1126/science.1224648>

Matthews, Thomas J. and Hamilton, Brady (2009). "Delayed Childbearing: More Women Are Having Their First Child Later in Life.” National CENTER FOR HEALTH STATistics, Data Brief No. 21. <https://www.cdc.gov/nchs/data/databriefs/db21.pdf>

Morrison, Peter and Bryan, Thomas (2009). "Targeting Spatial Clusters of Elderly Consumers in the USA." Population Research and Policy Review, 29, 33-46. <https://doi.org/10.1007/s11113-009-9149-2> 
Morrison, Philip S. and Clark, William A. V. (2016). "Loss Aversion and Duration of Residence." Demographic Research, 35, 1079-1100.

<https://doi.org/10.4054/DemRes.2016.35.36>

Mulder, Clara (1993). Migration Dynamics a Life Course Approach. Amsterdam: Thesis Publishers-PDOD Publications. <http://hdl.handle.net/11245/1.392642>

- (2003). "The housing consequences of living arrangements in young adulthood." Housing Studies, 18 (5), 703-719. <https://doi.org/10.1080/02673030304255>

- (2006). "Population and Housing: A Two-Sided Relationship." Demographic Research, 15, 401-412. <https://doi.org/10.4054/DemRes.2006.15.13>

- (2007). "The Family Context and Residential Choice: A Challenge for New Research." Population, Space and Place, 13 (4), 265-278. $<$ https://doi.org/10.1002/psp.456>

Mulder, Clara and Malmberg, Gunnar (2014). "Local Ties and Family Migration." Environment and Planning A, 46, 2195-2211. <https://doi.org/10.1068/a130160p>

Mulder, Clara and Smits, Annika (2013). "Inter-generational Ties, Financial Transfers and Home-ownership Support." Journal of Housing and the Built Environment, 28, (1), 95-112. <https://doi.org/10.1007/s10901-012-9302-9>

Mulder, Clara AND SMITS, Jeroen (1999). "First-time Home-ownership of Couples: The Effect of Inter-generational Transmission.” European Sociological Review, 15 (3), 323-337. <https://doi.org/10.1093/oxfordjournals.esr.a018266>

Mulder, Clara and van Der MeER, Marieke (2009). "Geographical Distances and Support from Family Members.” Population Space and Place, 15, 381-399. <https://doi.org/10.1002/psp.557>

Mulder, Clara and Wagner, Michael (1998). "Migration and Marriage in the Lifecourse: A Method for Studying Synchronized Events." European Journal of Population, 9, 55-76.

<https://doi.org/10.1007/BF01267901>

- (2001). "The Connections between Family Formation and First-time Home Ownership in the Context of West Germany and the Netherlands." European Journal of Population, 17, 137-164. <https://doi.org/10.1023/A:1010706308868>

- (2012). "Moving after Separation: The Role of Location-specific Capital." Housing Studies, 27 (6), 839-852. <https://doi.org/10.1080/02673037.2012.651109>

MYERS, Dowell (ed.) (1996). Housing Demography: Linking demographic Structure and Housing Markets. Madison: University of Wisconsin Press.

Nicoletti, Cheti and Rabe, Birgitta (2012). "Inequality in Pupils Test Scores: How Much do Family, Sibling Type and Neighborhood Matter?” Economica, 80, 197-218. <https://doi.org/10.1111/ecca.12010>

Nieuwenhuis, Jaap and HoOIMEIJER, Peter (2016). "The Association between Neighbourhoods and Educational Achievement, a Systematic Review and Meta-Analysis." Journal of Housing and the Built Environment, 31 (2), 321-347. <https://doi.org/10.1007/s10901-015-9460-7> 
ODLAND, John and SHUMWAY, Martin (1993). "Interdependencies in the Timing of Migration and Mobility Events." Journal of the Regional Science Association, 72, 221-237. <https://doi.org/10.1007/BF01434274>

OisHI, Shigehiro S. (2010). "The Psychology of Residential Mobility: Implications for the Self, Social Relationships, and Well-Being." Perspectives on Psychological Science, 5, 5-21. <https://doi.org/10.1177/1745691609356781>

OishI, Shigehiro, IsHII, Keiko and Lun, Jonathan (2009). "Residential Mobility and Conditionality of Group Identification." Journal of Experimental Social Psychology, 45, 913-919.

<https://doi.org/10.1016/j.jesp.2009.04.028>

Oishi, Shigehiro, MiaO, Felicity, KoO, Minkyung, Kissling, Jason and Ratliff, Kate A. (2012). "Residential Mobility Breeds Familiarity-seeking." Journal of Personality and Social Psychology, 102,149-162. <https://doi.org/10.1037/a0024949>

Oishi, Shigehiro, Rothman, Alexander J.,_Snyder, Mark, Su, Jenny, Zehm, Keri, Hertel, Andrew W.,_Gonzales, Marti Hope and Sherman, Gary D. (2007). "Socio-Ecological Model of Pro-Community Action: The Benefits of Residential Stability." Journal of Personality and Social Psychology, 93, 831-844. <https://doi.org/10.1037/0022-3514.93.5.831>

PAIS, Jeremy, South, Scott J. and Crowder, Kyle (2009). "White Flight Revisited: A Multiethnic Perspective on Neighborhood Out Migration.” Population Research and Policy Review, 8, 321-346. <https://doi.org/10.1007\%2Fs11113-008-9101-x>

Paldam, Martin (2000). "Social Capital: One or Many? Definition and Measurement." Journal of Economic Surveys, 14 (5), 629-653. <https://doi.org/10.1111/1467-6419.00127>

Parker, Jennifer, WoOdruff, Tracy, Basu, Rupaand and Schoendorf, Kenneth (2005). "Air Pollution and Birth Weight Among Term Infants in California." Pediatrics, 115, 121-128. <https://doi.org/10.1542/peds.2004-0889>

Priemus, Hugo (2012). "Managing Social Housing." In: Clapham, David, ClarK, William A. V. and GiBB, Kenneth (eds.). The Sage Handbook of Housing Studies. London: Sage. <https://doi.org/10.4135/9781446247570.n24>

Quillian, Lincoln (2003). "How Long are Exposures to Poor Neighborhoods? The Long-term Dynamics of Entry and Exit from Poor Neighborhoods." Population Research and Policy Review, 22 (3), 221-249. <https://doi.org/10.1023/A:1026077008571>

RABE, Birgitta AND TAYLOR, Mark (2010). "Residential Mobility, Quality of Neighborhood and Life Course Events." Journal of the Royal Statistical Society A, 173, 531-555. <https://doi.org/10.1111/j.1467-985X.2009.00626.x>

RindFuss, Ronald, Gray Swicegood, C. AND RosEnFELD, Rachael (1987). "Disorder in the Life Course: How Common and Does it Matter?" American Sociological Review, 52, 785-801. $<$ https://doi.org/10.2307/2095835>

Ritz, Beate, Yu, Fei, CHAPA, Guadalupe and Fruin, Scott (2000). "Effect of Air Pollution on Preterm Birth Among Children Born in Southern California Between 1989 and 1993." Epidemiology, 11, 502-511.

<https://doi.org/10.1097/00001648-200009000-00004> 
Rogerson, Peter (1996). "Geographic Perspectives on Elderly Population Growth." Growth and Change, 27, 75-95. <https://doi.org/10.1111/j.1468-2257.1996.tb00897.x>

Rogerson, Peter, Weng, Richard H. and Lin, Ge (1993). "The Spatial Separation of Parents and Their Adult Children." Annals of the Association of American Geographers, 83, 656-671. <https://doi.org/10.1111/j.1467-8306.1993.tb01959.x>

RonALD, Richard (2008). The Ideology of Homeownership: Homeowner Societies and the Role of Housing. London: Palgrave-MacMillian

Ronald, Richard and Elsinga, Marja (eds.) (2012). Beyond Homeownership. New York: Routledge.

Rossi, Peter (1955). Why Families Move. New York: MacMillian

Sage, Jo, Evandrou, Maria and Falkingham, Jane (2014) "The Timing of Parental Divorce and Filial Obligations to Care for Aging Parents." Families, Relationships and Societies, 3 (1), 113-30. <https://doi.org/10.1332/204674313X673509>

Sampson, Robert, Raudenbush, Stephen and Earls, Fenton (1997). "Neighborhoods and Violent Crime: A Multilevel Study of Collective Efficacy." Science, 277 (5328), 918-924. <https://doi.org/10.1126/science.277.5328.918>

SCHELling, Thomas (1971). "Dynamic Models of Segregation." Journal of Mathematical Sociology, 1 (2), 143-186. <http://dx.doi.org/10.1080/0022250x.1971.9989794>

South, Scott J. and Crowder, Kyle, D. (1997). "Escaping Distressed Neighborhoods: Individual, Community, and Metropolitan Influences." American Journal of Sociology, 102 (4), 1040-1084. <https://doi.org/10.1086/231039>

South, Scott J., Crowder, Kyle and Chavez, Eric (2005). "Exiting and Entering High-Poverty Neighborhoods: Latinos, Blacks and Anglos Compared.” Social Forces, 84 (2), 873-900. <https://doi.org/10.1353/sof.2006.0037>

South, Scott J., PAIS, Jeremy and Crowder, Kyle (2011). "Metropolitan Influences on Migration into Poor and Nonpoor Neighborhoods." Social Science Research, 40, 950-964. <https://doi.org/10.1016/j.ssresearch.2011.01.003>

SpeAre, Alden (1970). "Homeownership, Life Cycle Stage and Residential Mobility." Demography, 7, 449-458. <https://doi.org/10.2307/2060237>

Speare, Alden, Goldstein, Samuel and Frey, William (1974). Residential Mobility, Migration and Metropolitan Change. Cambridge, MA: Ballinger.

Steele, Fiona, Clarke, Paul and Washbrook, Elizabeth (2013). "Modeling Household Decisions Using Longitudinal Data from Household Panel Surveys, with Applications to Residential Mobility." Sociological Methodology, 43 (1), 220-271. <https://doi.org/10.1177/0081175013479352>

STOUfFER, Samuel (1940). "Intervening Opportunities: A Theory Relating Mobility and Distance." American Sociological Review, 5, 845-867.

Thomas, Michael. J., Stillwell, John C. H and Gould, Michael I. (2016). "Modelling the Duration of Residence and Plans for Future Residential Relocation: A 
Multilevel Analysis." Transactions of the Institute of British Geographers, 41, 297-312. <https://doi.org/10.1111/tran.12123>

Uzzell David, Pol, Franquesa and Badenas, David (2002). "Place Identification, Social Cohesion, and Environmental Sustainability." Environment and Behavior, 34 (1), 26-53.

<https://doi.org/10.1177/0013916502034001003>

VAN HaM, Maarten and FeIJTEN, Peteke (2008). "Who Wants to Leave the Neighbourhood? The Effects of Being Different from the Neighbourhood Population on Wishes to Move." Environment and Planning A, 40 (5), 1151-1170.

<https://doi.org/10.1068/a39179>

van Ham, Maarten, Manley, David, Bailey, Nick, Simpson, Ludi and Maclennan, Duncan (eds) (2012). Neighbourhood Effects Research: New Perspectives. Dordrecht: Springer.

- (2013). Understanding Neighbourhood Dynamics. Dordrecht: Springer.

WARnER, Cody and SHARP, Gregory (2016) "The Short- and Long-term Effects of Life Events on Residential Mobility." Advances in Life Course Research, 27, 1-15. <https://doi.org/10.1016/j.alcr.2015.09.002>

Woldoff, Rachel (2002). "The Effects of Local Stressors on Neighborhood Attachment." Social Forces, 81 (1), 87-116. <https://doi.org/10.1353/sof.2002.0065>

WoOd, Gavin and ONG, Rachel (2011). Sustaining Home Ownership in the $21^{\text {st }}$ Century: Emerging Policy Concerns. Australian Housing and Urban Research Institute: AHURI-RMIT Research Centre.

Wyly, Elvin and Holloway, Steven (2002). "Disappearance of Race in Mortgage Lending." Economic Geography, 78, 129-169.

<https://doi.org/10.1111/j.1944-8287.2002.tb00181.x>

Yates, Judith (2012). "Housing Subsidies.” In: Clapham, David; ClarK, William A. V. and GiBB, Kenneth (eds.). The Sage Handbook of Housing Studies. London: Sage. <https://doi.org/10.4135/9781446247570.n21>

ZHANG, Junfu (2004). “A Dynamic Model of Residential Segregation.” Journal of Mathematical Sociology, 28, 147-170. <https://doi.org/10.1080/00222500490480202>

Zorn, Peter (1989). "Mobility-Tenure Decisions and Financial Credit: Do Mortgage Qualification Requirements Constrain Homeownership?” Real Estate Economics, 17 (1), 1-16.

<https://doi.org/10.1111/1540-6229.00470> 